التحكيم في المنازعات الرياضية في القانون المصري والفرنسي

\title{
"دراسية مقارنةتة"
}

* محمد عبد التواب عبد الحسبب

\section{topa20052006@yahoo.com}

\section{ملخص:}

في ظل الاتجاه العالمي لفض المنازعات الرياضية بالطرق غير القضائية كان يتعين البحث عن آلية قانونية لحل النزاعات الرياضية في مصر وفرنسا، حتي نضـمن عدم لجوء أي من الرياضيين وأطراف المنازعات الرياضية إلى ساحات المحاكم، لما تحظى بـه المنازعات الرياضية من طبيعة خاصـة تجعل من الأفضل عدم تصدي المحاكم للفصل فيها، لذلك أصدر المشرع المصري قـانون الرياضــة رقم 71 لسـنة 2017، كمـا نـص على إنشـاء مركز التسـوية والتحكيم الرياضـي المصري ونفس الأمـر بالنسبة إلى المشرع الفرنسي أصدر

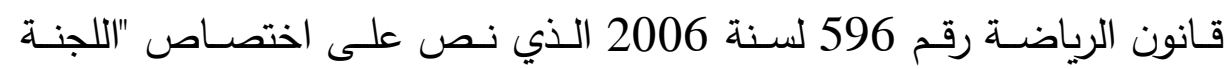
الوطنية الأولمبية والرياضة الفرنسية بالفصل في المنازعات الرياضية من خلال التوفيق بين المرخصـين والجمعيـات الرياضـية والاتحـادات الرياضـية المعتمـدة باستثناء النزاعات التي تشمل المنشطات. الكلمات المفتاحية: القانون المصري - المنازعات الرياضية - قانون الرياضـة المصري - اللجنة الوطنية الأولمبية.

* باحث دكتوراة - كلية الحقوق - جامعة عين شمس.

محمد عبد التواب (التحكيم في المنازعات الرياضية في القانون المصري.........) 


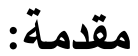

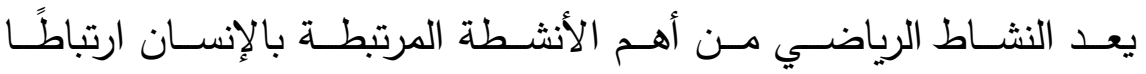

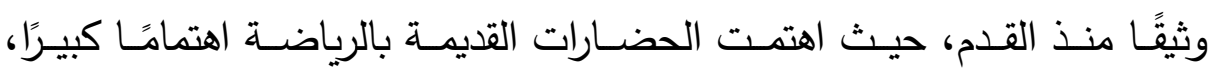
وفي مقـدمتها الحضــارة المصـرية القديمـة، والـليل على ذلك مـا تم رصــه على جــران المعابــــ الفرعونيـة مـن رسـومات يستثـف منهـا مـدى اهتمـام

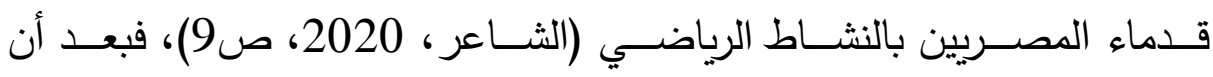

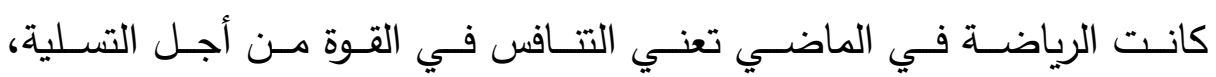

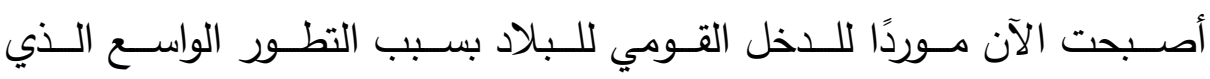
شهدته الرياضة في الوقت الحالي (لازم، 2019، ص99).

وتحتل الرياضــة مكانـة هامـة في المجتهـع بصـرف النظر عمـا إذا كانت

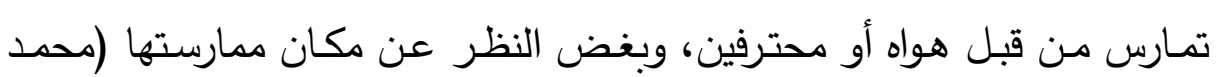

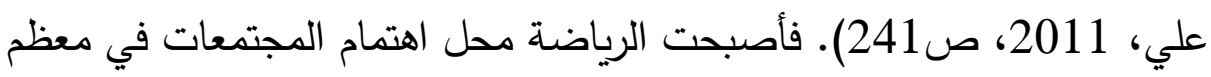
الـدول؛ حيـث بـات تأثيرهـا ملموسًا على كافـة منــاحي الحيـاة الاقتصـادية والاجتماعية وغيرها (ملكاوي، 2020، ص164)، فلا يستطيع أحد إنكار دورها في حيـاة الثـعوب، كونهـا ظـاهرة اجتماعيـة لا تتوقف عن النـو والانتشـار ؛

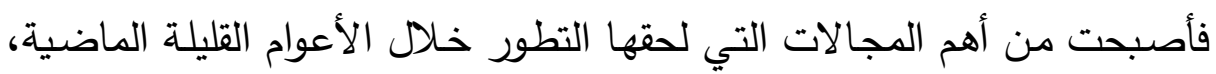
فصـارت تجذب انتباه الجمـاهير الغفيرة، ويخصص لهـا العديد مـن سـاعات العرض على شاشات التلفاز ، وتهتم بها الصحافة اهتمائًا غير عادي (شوقي

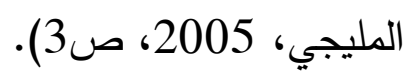

محمد عبد التواب

(التحكيم في المنازعات الرياضية في القانون المصري........) 
ومع ازدياد الاستثمار في شتى مجالات الرياضة المختلفة، تتوعت التعاقدات المتعلقة بهذه الأنشطة، وأصبح هناك حاجة ملحة للجوء إلى التحكيم للفصل في التي المنازعات التي تنشأ في هذا المجال.

\section{موضوع الاراسة وأهميته:}

لعل أصعب ما يواجه الباحث هو اختياره لموضوع بحثه ويرجع السبب في ذلك لما يقتضيه هذا الإختيار من جهد في الحصول على مصادر لهذا البحث وفي التقصي عن بعض المشكلات الجديرة بالتعمق في دراستها ونظرًا لأهمية التحكيم في المنازعات الرياضية علي النحو السـابق بيانه كوسيلة لفض هذه المنازعات فهو يحتاج إلي دراسة مستفيضة ومتخصصة لاسيما وأن القضاء ظل لفترات طويلة هو المختص بالفصل وحدة في تلك المنازعات.

\section{المنهج المتبع:}

التزامًا من الباحث بالعملية البحثية وطبيعة موضوعه فاعتمد الباحث على عدة منـاهج تتطلق من القواعد العامـة الى التطبيق الجزئي على نقاط البحث

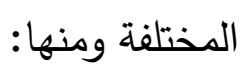

أولًا: المــهـج المقـــارن الذي يعتمــ على المقارنـة بـين الأنظمـة القانونيـة الوطنيـة السـائدة في فرنسـا ومصـر وبيـان دور التحكيم الرياضـي في كل مـن البلدين.

محمد عبد التواب (التحكيم في المنازعات الرياضية في القانون المصري.........) 
ثانيًا: المسنهج الوصـفي التحليلـي الذي يقوم على وصف فكرة التحكيم الرياضـي وإبـراز دوره في فض المنازعـات الرياضـية محل الدراســة مـن خـلال تحليل وفهم النصوص القانونية ذات الصلة بموضوع البحث في فرنسا ومصر بهدف الوصول الى وصف علمي متكامل لهذا الدور . ثالثًا: المنهج النقدي من خلال إبراز رأي الباحث في بعض المسائل محل الخـلاف سواء الخـلاف الفقهي أو القضـائي محل البحث خصوصًا فكرة التحلل من اللجوء إلى القضــاء لفض هذا النوع مـن المنازعـات إلى التحكيم كوسيلة لفضها، كما يبرز هذا المنهج النقدي من خلال استعراض رأي الباحث في بعض الأحكام القضـائية الصـادرة في هذا الثأن، ليس من قبيل التعليق أو القدح في هذه الأحكام، ولكن في إطار العسي للخروج من هذه الأحكام بالدرس والفائدة، كنحو استتباط ضوابط تشريعية ودستورية في ضوء الفلسفة التي يقوم عليها نظام التحكيم الرياضي وفقًا لقانوني التحكيم الرياضي المصري والفرنسي. 


\section{المبحث الأول}

\section{المقصود بالتحكيم في المنازعات الرياضية وطبيته}

يتطلب بيان المقصود بالتحكيم في المنازعات الرياضية أن نتناول مفهوم الرياضة، حيث إن هذا المفهوم اختلف قديمًا عنه الآن باختلاف التصور السائد للرياضة في المجتمعات القديمة عن عالمنا اليوم، فقديمًا كان ينظر إلي الرياضـة على أنها مجرد لعبة يمارسها الثخص علي سبيل التسلية، وذلك بهدف تقويـة الجسم والترويح عن النفس وتمضية أوقات الفراغ، فكان لا ينظر إليها على أنها قد تكون حرفة يمتهنها الشخص (عبداللاه، 2008، ص2)، يمكن من خلالها أن يحقق ربح مادي مباشر (Grande, 1985, p. 9767).

ووفقًا لهذا المفهوم التقليدي للرياضة عرف البعض الرياضـة بأنها: "الألعاب التي يكون من شأنها تقوية الجسم واستكمال أسباب الصحة" '.

ويـرى البعض أن هذا المفهوم التقليدي للرياضــة، لا ينطبق سـى على العامـة الذين يمارسون الرياضـة، إمـا لتقويم الجسم أو للتسلية أو كونها هواية للبعض، أمـا الأشـخاص الآخرون من الرياضيين المحترفين المتفرغين لها، الذين يجيدون أدائها بالتدريب المستمر بهدف الربح مقابل انتصارهم بلعبتهم، فلا ينطبق هذا المفهوم التقليدي عليهم (عبداللاه، 2008، ص2) خصوصًا بعد أن أصبحت ممارسة الرياضـة وتتظيمها حرفة يمتهنها بعض الرياضيين أنفهم ومنظمي الأنشطة الرياضية (محد علي، 2011، ص242-241).

محمد عبد التواب (التحكيم في المنازعات الرياضية في القانون المصري........) 
لهـذا الأمـر تغير التصـور التقليدي للرياضـة، وأصـبح ينظر إلى مفهوم الرياضـة نظرة مختلفة، حيث اتجهـ الفقه الحديث إلى تعريف الرياضــة بأنها: "نثاط ترويجي يهدف في الأساس إلى تقوية القدرات البدنية ويعد في آن واحد

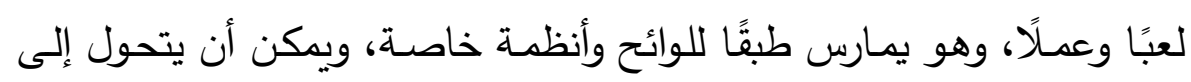
نشاط حرفي" (Magane, 1967, p.1670)، وكذلك هي: "نشاط ترفيهي تخـلط مـن خلالـه الرياضــة بالعمـل ويخضــع الرياضـي في ممارسـته للـوائح

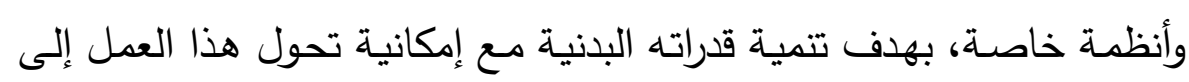
نشاط حرفي". (الحفني، 1995، ص5).

أما من حيث المقصود بالتحكيم في المنازعات الرياضية باعتباره إحدى الطرق والوسائل الاختيارية السابقة على اللجوء إلى القضـاء إلى جانب بعض الجهات الداخلية المختصة بحسم المنازعات الرياضية، كاللجوء إلى الاتحادات الوطنية - على سبيل المثال - فما المقصود بالمنازعات الرياضية؟ وما هي أنواعها؟ وما هو موقف كل من المشرعين الفرنسي والمصري من التحكيم في تلك المنازعات، وذلك ما نوضحه على النحو الآتي: 


\section{المطلب الأول}

\section{المقصود بالمنازعات الرياضية وأنواعها}

\section{أولًا: المقصود بالمنازعات الرياضية:}

يقصــ بالمنازعـات الرياضـية كل نـزاع أو خـلاف قـانوني بصـدد علاقـة

قانونيـة ذات طـابع رياضــي مـن أي نـوع كانـــ (الزهيـري، السـنـة الحاديـة والستون، ص10)؛ فالمنازعات الرياضية لم تعد تقتصر على ممارسة النشاط الرياضـي مـن الناحيـة البدنيـة فقط، بـل امتدت لتثـمل كل مـا يتعلق بـإدارة الرياضــة والإشـراف عليهـا وتتظيم العلاقـات بـين القـائمين عليهـا (الشـاعر، 2020، ص12). فقد يكون سبب النزاع مثثلً اختراق أحد أطراف المنازعة لعقد من العقود المبرمة بينهما سواء كان عقد احتراف أم عقد انتقال لاعب بيع

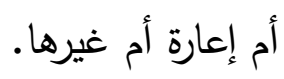

فالمنازعـات الرياضـية قد تكون ذات طبيعـة تجاريـة تتشـأ بمناسبة تنفيذ العقود المتعلقة بالرياضـة، كعقود الرعايـة وعقود بيع حقوق البث وعقود بيع وإعارة اللاعبين والمدربين، وقد تكون المنازعة الرياضية ذات طبيعة تاديبية، كالمنازعـات التـي تتعلـق بالمنشـطات وعقوبـات أعمـال الثــب بالملاعـب المختلفـة والسـب والقـذف، وقـد تكـون المنازعـة ذات طبيعـة محليـة، أو ذات

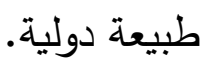

محمد عبد التواب (التحكيم في المنازعات الرياضية في القانون المصري.......) 


\section{ثانيًا: أنواع المنازعات الرياضية:}

مها سبق يمكن أن نفرق بين نوعين من المنازعات الرياضية نتناولهها

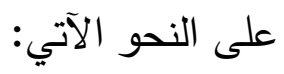

أ- المنازعـات الرباضـية الدوليـة: (شوقي المليجي، 2005، الصفحات $\underline{.(15-12}$

يقصد بها تلك المنازعات التي تقع نتيجة دخول عنصر أجنبي في العلاقة الرياضية سواء تعلقت تلك المنازعة بأطراف العلاقة، نظرًا لاختلاف جنسياتهم أو بمصدر تلك العلاقة، كالعقود المبرمسة بينهم أو بموضوعها كالمشاركة في بطولة قاريـة أو دولية، وممـا سـاعد على ذلك تحول العالم إلى قريـة صغيرة، نظـرًا للتطـور السـريع الـي لحق بوسـائل المواصـلات ووسـائل الاتصـالات، وأصـبحت الحـدود وبعـد المسـافات غيـر عـائق للحركـة الرياضـية العالميـة، والأمثلـة على تلـك المنازعـات كثيـرة؛ فقـــ تتشـأ بـين الاتحــادات الرياضـية المختلفة، كالمنازعات الناشئة بين الاتحاد الرياضـي الوطني وآخر أجنبي أو بين اتحاد دولتين تـابعين لاتحـاد قـاري واحد أو لاتحـادين قـاريين مختلفين ولكنهما يخضعان لاتحاد دولي واحد، بمناسبة مقابلة رياضية بينهم، تضمنت أحداثًا تشكل خروجًا على قواعد اللعبة أو خروجًا عن القواعد والأعراف الدولية التي تـم إقرارهـا مـن قبـل التنظيمـات العالميـة التـي ينتمـي إليهـا الاتحـادان المتنازعان أو المنازعات التي تتشأ بين أحد الأندية الرياضية الوطنية وآخر

محمد عبد التواب

(التحكيم في المنازعات الرياضية في القانون المصري.......) 
أجنبيًا أو بين أحدهما وأحد اللاعبين الأجانب بخصـوص عقد الأخير مـع النادي، ومـا ينتج عن ذلك العقد من مستحقات لأحد اللاعبين الأجانب أو الو مطالبة النادي اللاعب بتنفيذ التزامه.

ب- المنازعـة الرباضية الداخليـة: (شوقي المليجي، 2005، الصفحات

$\underline{:(104-100}$

هي تلك التي تقتصـر فيها المنازعـة الرياضية على طرفين وطنيين لا يكون لهما الصفة الدولية، بالإضافة إلى أن موضوع تلك المنازعة أو مصدرها وطنيًا يحكمها قواعد القانون الوطني.

فمنح المشرع المصري الهيئات الخاصـة بالثباب والرياضـة2 الكثير من امتيازات السلطة العامـة واعتبر أموالها من الأموال العامـة في مجال تطبيق قانون العقوبات وحظر الحجز عليها إلا لاستيفاء الضرائب والرسوم المستحقة للدولة، كما حظر تملكها بمضي المدة3.

ومن أمثلة تلك الامتيازات فى فرنسـا ذلك التفويض الوزارى الذي يمنح الاتحاد الرياضي الفرنسي تمثيل النشاط الرياضـي الذي يتولاه الاتحاد المذكور علي المستوي الوطني والدولي، وكذلك لـه الحق في اختيار المنتخب الوطني في الرياضة التي يشرف عليها.

محمد عبد التواب

(التحكيم في المنازعات الرياضية في القانون المصري.......) 
المطلب الثاني

المقصود بالتحكيم في المنازعات الرباضية وموقف المشرع

الفرنسي والمصري

أولاً: المقصود بالتحكيم في المنازعات الرباضية:

يقصد بالتحكيم في المنازعات الرياضية أنه: "هو وسيلة يتم من خلالها عرض المنازعة الرياضية على محكم أو مجموعة محكمين سشرط أن يكون عددهم وترًا - لغرض الفصل فيها بقرار ملزم، لذلك هي وسيلة للاتحـادات والجمعيـات واللجـان الأولمبيـة والدوليـة المعتمـدة ضـمن أنظمـة هذه الهيئات الرياضـية وجميـع المؤسسـات الرياضـية ولوائحهـا" (لازم، 2019، ص28)،

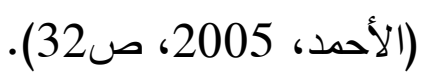

فالتطور الهائل في مجال الأنشطة الرياضية -كما سبق القول- أدى إلى ظهور العديد من المنازعات بين أطراف النشاط الرياضي، الأمر الذي أدى بدوره إلى ضـرورة وجود قانون رياضسي مستقل ومتميزعن القوانين الأخرى4. ولعل من العوامل المهمـة التي تبرز مدى أهميـة استقلال القانون الرياضـي وتميزه، هو تقرد هذا القانون بقضاء تحكيمي خاص بمعنى وجود جهات تحكيم تختص بـالنظر : "في المنازعـات التي تنجم عن ممارسـة مختلف الأنشطة الرياضية، سواء تعلقت بالرياضة ذاتها أو ما يتم من علاقات بمناسبتها كعقود البث التلفزيوني مثلًا؛ فضلًا عن وجود هيئات لها اختصاص استئنافي مهنها

محمد عبد التواب

(التحكيم في المنازعات الرياضية في القانون المصري.......) 
النظـر في المنازعـات الرياضـية أيضًا. ويتميـز عمـل هـذه الهيئـات بالدقـة والموضوعية البالغة، فإجراءاتها تتسم بالبساطة وعدم التعقيد، وتتسم جلساتها بالسرية التامة، إذ إن أطراف النزاع ملزمون بعدم الافصاح عن تفاصيله. كما أنها تأخد بعين الاعتبار إرادة الأطراف وخيـاراتهم، ممـا يضـمن بقاء المـودة قائمة بينهم. ويتم التحكيم في هذه الهيئات وفق القانون الذي يختاره الأطراف وبخلافـه يـتم النظر فيـه بموجب قـانون محل المنظمـة الرياضـية. لكل هذه الأسباب فإن هذا النوع من القضاء يناسب المنازعات الرياضية الدولية ".

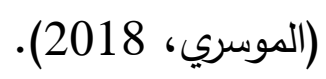

\section{ثانتًا: موقف المشرعين الفرنسي والمصري:}

أولـى المشـرعين الفرنسـي والمصـري اهتماءًا كبيـرًا بأهميـة إقـرار قـانون للرياضــة متماشيًا مـع مـا نصـت عليه الاسـاتير في هذا الشأن، وهو مـا نبينه بالتفصيل على النحو الآتي:

\section{أ - موقف المثرع المصري:}

نص الدستور المصري المعدل 5 في المادة 82 من الباب الثالث والخاص "بالحقوق والحريـات والواجبات العامـة" على اهتمامـه بالثباب باعتبار أن لهم الدور الكبير والمهم في تتمية المجتمعات وبنائها، لأنهج ركائز أي أمسة وأساس الإنماء والتطور فيها وبناه مجدها وحضارتها وحماتها.

محمد عبد التواب (التحكيم في المنازعات الرياضية في القانون المصري.......) 
فنصس المادة 82 على أن: "تكفل الدولـة رعايـة الثباب والنشء وتعدل على اكتثـاف مـواهبهم، وتتميـة قدراتهم الثقافيـة والعلميـة والنفسـية والبدنيـة والإبداعية، وتشجيعهم على العمل الجماعى والتطوعى، وتمكينهم من المشاركة

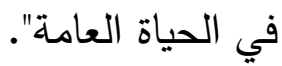

فقد أصـدر المشرِعِع المصـري في البدايـة القـانون رقم 77 لسنة 1975 بشـأن الهيئـات الخاصـة بالشـباب والرياضــة، وهـي كـل جماعـة ذات تتظـيم مستمر تتألف من عدة أشخاص طبيعيين أو اعتبارين لا تستهدف الكسب المادي، ويكون الغرض منها تحقيق الرعاية للشباب وإتاحة الظروف المناسبة لتتميـة ملكـاتهم، وذلــك عـن طريـق تـوفير الخــدمات الرياضــية والقوميـة والاجتماعيـة والروحيـة والصـحية والترويحيـة في إطـار السياسـة العامـة للدولـة والتخطيط الذي يضعه المجلس الأعلى للشباب والرياضة.

وتخضع الهيئات الخاصـة لرعاية الثباب والرياضـة ماليَّا وتتظيميَّا وإداريًّا وفنيًا لإشـراف الجهـة الإداريـة المختصــة (مديريـة الثـباب والرياضــة) (مـادة 1/25)، وينظِّم القانون رقم 77 لسنة 1975 تشكيل واختصاصـات الجمعيات العمومية لهذه الهيئات.

وهو مـا أكدت عليه المحكمة الإداريـة العليا في أكثر من مناسبة حين قررت أن: "الهيئـات الخاصــة بالثـباب والرياضــة (ومنهـا النـوادي الرياضـية) تخضع في سبيل قيامها برسالتها المنوطة بها برقابة الجهة الإداريـة المختصـة التي تملك بسط الرقابة على جميع الإجراءات التي تتخذ سواء من الناحية 


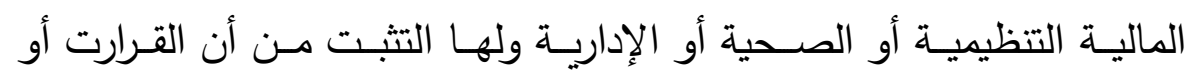
الإجراءات التي اتخذتها لم تخـالف نصًا في القوانين أو اللوائح أو القرارات المنفذة لها، وإنها لم تحد عن السياسة العامة التي وضعتها الجهة الإدارية لها ــلجهة الإدارية في حالة اكتشافها أية مخالفة سلطة إبطال القرارات المنطوية على المخالفة وعدم الاعتداد بها- امتتاعها عن ذلك يعد قرارًا إداريَّا سلبيَّا يختص القضاء الإداري بنظر الطعن عليه"6.

وقـد حـد القـانون سـابق الـذكر تلـك الهيئـات، وهـي اللجنـة الأولمبيـة

والاتحادات الرياضية والأنديـة الرياضية الأعضـاء في الاتحادات وسمح لها بمباشرة النشاط الرياضي وتتمتع كل منهما في مباشرة اختصاصاتها ونظامها الأساسي باستقلال تام.

وفيما يتعلق بالفصل في المنازعات الرياضية؛ فقد أوكل القانون المذكور الفصل فيما يطرأ من منازعات رياضية للجان الإداريـة كالوزير المختص أو المنظمات أو الهيئات الإدارية والاتحادات الرياضية من خلال لجان مختصـة مثل لجنـة تظلمـات الاتحـاد المصـري لكرة القدم (شـوقي المليجي، 2005، ص165) والتي لا تعد محكمـة قضـائية بـالمعني الفني الدقيق كونها مجرد لجنة من لجان اتحاد الكرة المصري وتختص بالنظر في التظلمات المرفوعة إليها بسبب النزاع على تطبيق أي من لوائح الاتحاد التي تعني بشؤن اللعبة وممارسيها أو بأحد عناصرها. (شوقي المليجي، 2005، ص168). 
وبـالرغم من كل مـا تضمنه القانون رقم 77 لسنة 1975 بشأن الهيئات الخاصـة بالثباب والرياضــة المعدل بالقانون رقم 51 لسنة 1978 من طرق لتسوية المنازعات الرياضية، إلا أنه أصبح لا يستطيع مواكبة التطور الهائل

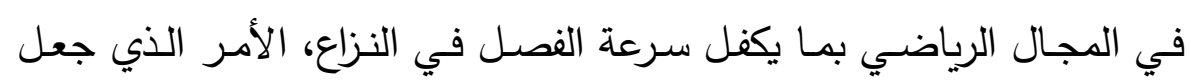
المشرع المصـري يبحث عن وضـع تشريعيًا جديدًا وأفضـل يواكب التطورات الحديثة التي طـرأت على الرياضــة والـذي خـلا مـن تتظيمها القـانون القديم المشـار إليه وعلى رأسها الطب الرياضسي والمنشطات والاستثمار في مجال الرياضة والمحاكم الرياضية المتخصصة.

لذلك صدر قانون الرياضة رقم 71 لسنة 20177، وفيه أفرد المشرع بابًا كـاملًا كوهـو البـاب السـابع- للمنازعـات الرياضـية، تحــت عــوان: "تسـوية المنازعات الرياضية" والذي يتكون من خمسة مواد.

وهو الأمـر الذي شَّلَ تطورًا تشـريعيَّا كبيرًا في مجـال تتظيم النشـاط الرياضي بجوانبه المختلفة، بما في ذلك الأخد بنظام التحكيم الرياضي، وإنشاء هيئة تحكيمية خاصـة بالفصل في المنازعات الرياضية، حيث نص القانون الجديد في المادة 66 منه على إنشاء "مركز التسوية والتحكيم الرياضي"، الذي يختص بالفصل في المنازعات الرياضية، وقد نظم القانون إجراءاته وكيفية تثكيل مجلس إدارته وهيئات التحكيم الخاصة به، وذلك على نحو ما ما سيرد بيانه بالتفصيل في الموضع التالي. 
ثم صدر القانون رقم 218 لسنة 2017 بإصدار قانون تنظيم الهيئات الثـبابية الـني حل محلـ قـانون الهيئات الأهليـة لرعايـة الثـباب والرياضــة الصادر بالقانون رقم 77 لسنة 1975.

\section{ب- موقف المشرع الفرنسي:}

وعلى غرار المشرع المصري، كان المشرع الفرنسي قد أصدر في

البدايـة - القـانون رقم 84/610 الصـادر في 16 يوليـو 1984 بثـأن تنظيم وتتميـة الأنشــة الجسـدية والرياضـية، والـذي وزع المسؤلية عـن

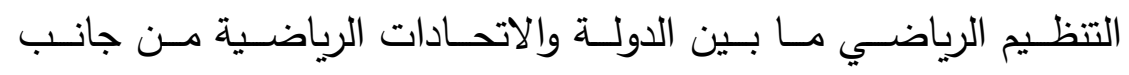
والقطاعات الرياضية الخاصة 9 من جانب آخر ، وفيما يخص طرق فض المنازعـات الرياضية؛ فقد أوجب القانون رقم 84/610 بالمـادة السادسـة عشر منه على كل اتحاد رياضي يشارك في مهمة تتعلق بخدمة عامة أن يأخذ بلائحة انضباط مطابقة لما تنص عليه لائحة الانضباط النموذجية للاتحــادات الرياضـية المنصـوص عليهــا بالمرسـوم رقـم 93/1059، والصادرة في الثالث من سبتمبر عام 1993، كما قرر المشرع في القانون

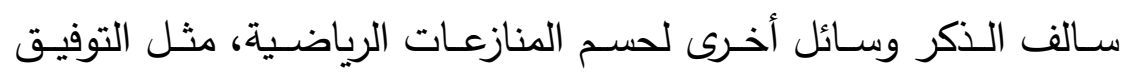
والتحكيم و اللجـوء إلـى القضــاء الإداري والعـادي. (شـوقي المليجـي،

$$
\text { 2005، ص119) }
$$

ونفس الأمـر بالنسبة إلى المشرع الفرنسي الذي قام هو الآخر بمواكبة التطورات الحديثة التي طـرأت على الأنشطة الرياضـية منـذ صـدور قانون 
الرياضــة رقم 84/610 سـالف الذكر ؛ فصدر قانون الرياضـة رقم 596 لسنة 2006 والذي ألغـى بـدوره قـانون الرياضــة الفرنسـي القديم، وتضـمن أحكامًا خاصة بتسوية المنازعات الرياضية والتحكيم. (Mamayou, 2006, p.116)

\section{المبث الثاني}

دور القضاء في فض المنازعات الرياضية والتطور نحو اللجوي إلى التحكيم

ممـا لا شك فيه أن النظام القضـائي في كل من مصـر وفرنسـا يتميزان بوجود جهتين قضـائين، وهما القضـاء العادي، والقضـاء الإداري، الأمر الذي قد يثير مشكلة تحديد اختصاصات كل منهما.

وقد اتجـه مجلس الدولـة المصـري إلى تحديد المسـائل التي تـدخل في ولايته 10، وإن كان هذا التحديد ليس على سبيل الحصر ، حيث تثور التساؤلات بخصوص طبيعة بعض المنازعات، وما إذا كانت منازعة يختص بها القضـاء العادي أم منازعة يختص بها القضاء الإداري.

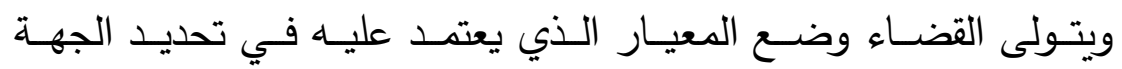
المختصــة بالفصـل في المنازعـات المطروحـة عليـه، وقد أخذ مجلس الدولـة المصري بالمعيار الموضوعي لاعتبار وصف القرار الإداري، وهو أن يكون بحكم موضـوعه وفحواه، وهو مـا أكدت عليه المحكمـة الإداريـة العليا، حيث

محمد عبد التواب

(التحكيم في المنازعات الرياضية في القانون المصري.......) 
قررت أن: "مجرد صـدور قرار عن جهـة إداريـة لا يخلع عليه بحكم اللزوم وصف القرار الإداري، إذ يتعين أن يكون كذلك بحكم موضوعه، وأن يكون

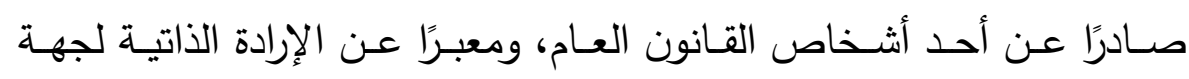
الإدارة، ومحدثًا لأثر قانوني، وليس مجرد تتفيذ للقوانين واللوائح التي تلزم بإصـداره - إذا دار القرار حول مسـألة مـن مسـائل القانون الخـاص أو تعلق بإدارة شخص معنوي خاص لم يكن قرارًا إداريًا - قرار الجهة الإداريـة باعتماد قرار الجمعيـة العموميـة غير العاديـة لثـركة مـن أشـخاص القـانون الخـاص بتعديل النظام الأساسي للشركة الذي تختص هذه الجمعية بتعديله لا يعد قرارًا إداريًا، ولا تختص محاكم مجلس الدولة بنظر الطعن فيهـامبل.

\section{المطاب الأول}

\section{دور القضاء في فض المنازعات الرياضية}

مع ازدياد المنازعات الرياضية زادت الحاجة إلى اللجوء إلى القضـاء من أجل التدخل لحل تلك المنازعات، كمـا زاد -في البداية، وقبل صدور قانون الرياضة المصري والفرنسي الحالي - الخلاف حول إمكانية اللجوء إلى قضـاء الدولة أم إلى جهـة أخرى مشكلة من عناصـر قانونية ورياضية متخصصسة تمثل الجهات التي نشب بشأنها النزاع، وهو الأمر الذي نتتاوله بالدراسة في قوانين كل من مصر وفرنسا، كما يلي:

محمد عبد التواب

(التحكيم في المنازعات الرياضية في القانون المصري.......) 


\section{أولًا: دور القضاء في فض المنازعات الرياضية في مصر:}

كان للقضاء دور كبير في فض المنازعات الرياضية في مصر في ظل القوانين التي كان معمولًا بها، وفي ظل القوانين الحالية، وهو ما نوضحه على

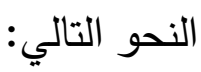

أ- دور القضاء في فض المنازعات الرياضية في ظل قانون الرياضسة الملغي رقم 77 لسنة 1975.

سمح قانون الرياضـة الملغي رقم 77 لسنة 1975 لأطراف المنازعة الرياضية اللجوء إلى جهتي القضـاء، حيث يختص القضـاء العادي بنظر الطعن في القرارات الصـادرة عن مجالس إدارة الهيئات الخاصـة بالثباب والرياضـة، على اعتبار أنها هيئات خاصـة ذات نفع عـام مـن أشخاص القانون الخاص وما يصدر عنها من تصرفات وما تصدره من قرارات لا تعتبر قرارات إداريـة: "فـلا تعد اللجنـة الأولمبيـة المصـرية أو غيرهـا من الهيئات الخاصـة للشباب والرياضـة من أشخاص القانون العام التي تضم أجهزة الحكومة ووحداتها الإداريـة ومصـالحها وهيئاتها العامـة، ومن ثم لا يعد ما يصدر عنها من قرارت إدارية"12.

كما أن القضـاء الإداري يختص هو الآخر بنظر تلك المنازعات، حيث أعطى المشرع المصـري للجهـة الإداريـة العليا - كوزير الشباب والرياضــة والجهة الإداريـة المركزيـة - كقطاع الرياضـة بوزارة الثباب - والجهة الإداريـة 
المختصـة - كمديريـة الثباب والرياضــة بالمحافظـة التابع لها الهيئة - سلطة التنظيم والرقابة على جميع الهيئات الخاصة الرياضية، ولهذا فإن القرارت التي تصـدر عنهـا، هـي قرارات إداريـة صـادرة مـن جهـة الإدارة بإرادتهـا المنفردة الملزمة لها وللآخرين، بقصد إحداث أثر قانوني تخضع لرقابة القضـاء الإداري عند الطعن عليها. (شوقي المليجي، 2005، صندئ 152، أيضًا 165). لهذا نجد أن محاكم مجلس الدولـة "تختص بنظر الطعن علي امتـاع الجهـة الإداريـة المختصــة عـن إبطـال قـرارات النـوادي الرياضـية المخالفــة

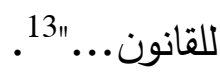

ونخلص مـن ذلك إلـى أن مجلس الدولـة المصـري، وفي ظـل القـانون السابق لا يختص بنظر الطعن في القرارات الصادرة عن مجالس إدارة الهيئات الخاصــة للشـباب والرياضــة وجمعياتهـا العموميـة في نطـاق الاختصاصـات المنوطـة بها قانونـا، والمستقلة عن الجهـة الإداريـة المختصـة، لكنها تختص بنظر الطعن في القرارات الصـادرة عن الجهة الإداريـة المختصـة وهي بصدد إعمال سلطتها في الإشراف والرقابة على هذه الأندية.14

ب- دور القضاء في فض المنازعات الرياضية في ظل قانون الرياضـة الحالي رقم 71 لسنة 2017.

نصـت المـادة 66 من قـانون الرياضــة الحسالي رقم 71 لسنة 201715 على أن: "ينثأ باللجنة الأولمبية المصرية مركز مستقل يسمى (مركز التسوية 
والتحكيم الرياضـي المصـري)، تكون لـه الثخصية الاعتباريـة، يتولى تسوية المنازعات الرياضية الناشئة عن تطبيق أحكام هذا القانون، والتي يكون أحد أطرافها من الأشخاص أو الهيئات أو الجهات الخاضعة لأحكام هذا القانون، وذلك عن طريق الوساطة أو التوفيق أو التحكيم الرياضي".

ويتضـح من النصوص السـابقة أن الجهة الوحيدة المختصـة التابع للجنـة الأولمبيـة المصـرية بالفصـل في النزاعـات الرياضـية في مصـر هو: "مركـز التسوية والتحكيم الرياضي" التابع للجنة الأولمبية المصرية، ولا يجوز لجهتي القضاء العادي والإداري التعرض لتلك المنازعات.

ولبيان دور القضاء في ظل قانون الرياضة الحالي، كان لمحكمة القضـاء الإداري رأي آخـر، في هـذا الصـدد حيـث رأت أن المشـرع في ظـل قـانون الرياضــة الجديـد رقم 71 لســنة 2017 جعـل سـلوك سـبيل مركـز التسـوية والتحكيم الرياضي سالف الذكر اختياريًا وليس إجباريَّا، ولم يحصنه من ولاية القضـاء، وهو مـا أكدت عليه المحكمة حين تعرضـت للدعوى بطلان قرارات الجمعيـة العموميـة لأحـد الأنديـة الرياضـية ــــادي الزمالك المصـري- فيمـا تضمنته من اعتماد نظام اللائحة الأساسية المنظمة للنادي، وحين تعرضت لدعوى مطالبة بوقف تتفيذ وإلغاء قرار رئيس اللجنة الأولمبية رقم 62 لسنة 2017 باعتبار لائحة النظام الاسترشادي للجنة الأولمبية هي لائحة النظام الأساسي للنادي الأهلي. 
وقالت المحكمـة في حيثيات حكمها: "إن قـانون الرياضــة السـابق كـان

يُخضـع الهيئات والأنديـة الرياضـية لوصـاية الجهـة الإداريـة متمثلـة في وزارة الثـباب والرياضــة والمجلس القومى للرياضــة، سـواء مـن الناحيـة الماليـة أو التتظيمية أو الصحية أو الإدارية، وكان يمنح الجهة الإدارية المختصـة حالة وجود أي مخالفة للقوانين أو اللوائح سلطة التدخل وتصـيح الأوضـاع بقرار إداري يصدر منها".

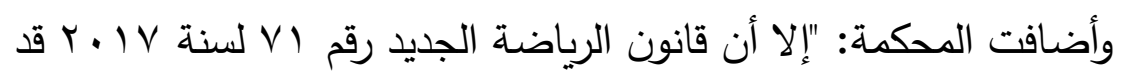
غـلّ يــــ الجهـات الإداريـة إلى حــ كبيـر عـن التـدخل في شـئون الهيئات الرياضـية، وأنـاط بتلك الهيئات اختصـاص وضـع سياستها العامـة، وتتظيم شـئونها بمـا يتفـق مـع المواثيـق الدوليـة، كمــا أخـرج القـرارات الصـادرة عـن الجمعيـات العموميـة لهذه الهيئـات مـن نطـاق رقابـة الجهات الإداريـة، وأنـاط باللجنة الأولمبية - التي تعد من أشخاص القانون الخاص - سلطة الموافقة على النظم الأساسية للهيئات الرياضية قبل نشرها بالوقائع المصرية". وتابعـت المحكمـة "وفِي ضـوه خلـو الأوراق ممــا يفيــــ وجـود شـرط أو مشارطة تحكيم بين طرفي الدعوى بشأن تسوية النزاع القائم بينهما أمام مركز التحكيم، الأمر الذي ينتفي معه اختصاص المركز بنظر تلك الدعاوى، وينعقد ذلك الاختصاص للمحكمة المدنية المختصة، وهي محكمة شمال القاهرة"16. ويتضـح من الحكم السـابق أن محكمة القضـاء الإداري أشترطت لإنعقاد الإختصــاص لمركـز التسـوية والتحكـيم الرياضــي للفصـل فـي المنازعـات محمد عبد التواب (التحكيم في المنازعات الرياضية في القانون المصري.......) 
الرياضية، أن يكون أحد طرفي المنازعة من الأشخاص أو الهيئات أو الجهات التي يسرى في شأنها هذا القانون، أو أن يكون هناك شرط أو مشارطة تحكيم وارد في عقــ يكـون أحــ أطرافـهـ مـن الأثـخاص أو الهيئـات أو الجهـات الخاضـعة لقانون الرياضـة، أو أن يتم الاتفاق على صياغة مشـارطة التحكيم إعمالا لما ورد في لائحة هيئة تكون خاضعة لأحكام قانون الرياضـة أو لائحة متعلقة بقانون الرياضة.

ومـع خلو الأوراق ممـا يفيـــ وجود شـرط أو مشـارطة تحكيم بـين طرفي الدعوى بشأن تسوية النزاع القائم بينهما أمسام مركز التحكيم، سلبت المحكمة سـلطة الاختصـاص بنظـر المنازعـة مـن مركز التسـوية والتحكيم الرياضـي، وإحالتــه إلى المحكمـة المدنيـة المختصـة، بإعتبـار أن القضــاء الإداري غيـر مختص بنظر تلك الدعوى.

\section{ثانيًا: دور القضاء في فض المنازعات الرياضية في فرنسا:}

كان قانون الرياضــة الفرنسي القديم يسمح بإمكانية اللجوء إلى القضــاء العادي والإداري، حيث نصت المادة 19 في فقرتها الثامنة من قانون الرياضـة - الملغي - الصادر في 16 يوليو 1984 تنص على أن: "المحكمة الإدارية التـابع لهـا محـل إقامـة أو المقـر الاجتمـــي للطـاعن وقـت صـدور القـرار المطعون عليه- هي المختصـة بالفصل في الطعون التي تقدم ضد القرارات 
الفرديـة التي تصــرها الاتحسادات الرياضـية بمقتضـي ممارسـاتها لإمتيـازات

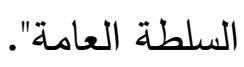

وبناءً عليه يختص القضاء الإداري الفرنسي بالنظر في الطعون المقدمة

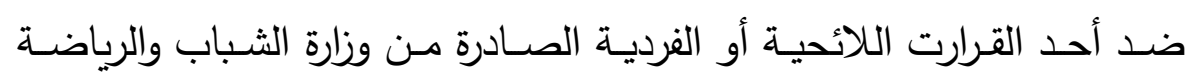
كالقرارات الصادرة من هذه الهيئات بالاعتراف بأحد الاتحادات الرياضية 17.

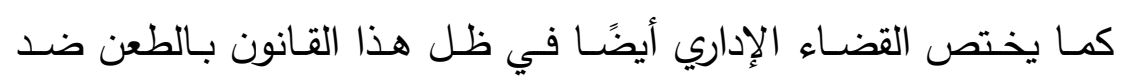
القرارات التأديبيـة الصـادرة مـن الاتحساد الرياضـي بعد أن يكـون الطـاعن قد الرد استتفذ كافة طرق الطعن الداخلية وفقًا للوائح الاتحاد من عرض الأمر على الجهـة المختصـة بالتأديت بالاتحـاد مـرورًا بعرضـهـ على جهـة الاستئناف إذا رغب أحد أطراف المنازعة في الطعن بالاستئناف، فإذا لم يلق قرار الاستئناف قبولًا يجب عليه اللجوء إلى إجراءات التوفيق المنصوص عليه في المادة 19 من قانون 16 يوليو 1984 سـالفة الذكر، وأخيرًا يلجأ إلى القضـاء الإداري للطعن على قرار الاتحاد الرياضي. (شوقي المليجي، 2005، ص127). وبالتالي يتضـح أن اللجوء إلى القضـاء الإداري، كأحد طرق الطعن على القرارات الصادرة من الاتحاد الرياضي المختص، هو آخر الطرق التي يطرقها الطاعن سعيًا وراء الحصول على حقه في ظل قانون الرياضـة القديم، كما أن القضــاء العـادي في ظـل قـانون الرياضــة الفرنسـي الصــادر في 16 يوليو 1984، يختص أيضَـا بنظـر الططعون المقدمـة ضــــ القرارت الصـادرة مـن الاتحادات الرياضية التي لم تتلقى تفويضًا من الوزير المختص بالنسبة لنشاط 
رياضي معين، حيث إنها مكلفة بخدمة عامـة دون أن تكون مفوضـة بمباشرة امتيازات السلطة العامة، وبالتالي فإن أعمالها تعد أعمالًا مدنية تخضع للقضاء العادي. (شوقي المليجي، 2005، ص130).

وفي ظل قانون الرياضة الفرنسي رقم 596 لسنة 2006، نجد أن المشرع كـان قد أفرد فصـلًا كـاملً عند تحديـده للجهـة المختصــة بنظر المنازعـات الرياضـية، وهـو الفصـل الأول، حيـث جـاء تحـت عنـوان: "اللجنـة الوطنيـة الأولمبيـة والرياضــة الفرنسية"، مـن البـاب الرابـع: "هيئـات التمثيـل والتوفيق"، ونصت الفقرة الرابعة من المادة 141 من هذا الفصل على اختصاص اللجنة الأولمبيـة الوطنيـة والرياضـية الفرنسية بالفصل في المنازعات الرياضية من خلال التوفيق في النزاعات بين المرخصين والجمعيات الرياضية والاتحادات الرياضية المعتمدة باستثناء النزاعات التي تثمل المنشطات.

\section{ثالثًا: رأي الباحث:}

مما لا شك فيه أن طبيعة الأنشطة الرياضية الخاصـة جعلت المنازعات

الرياضية تتمتع هي الأخرى بخصوصية تختلف عن غيرهـا من المنازعات القانونية الأخرى، لذلك يذهب الباحث مع البعض (الثاعر، 2020، ص24) (شــوقي المليجـي، 2005، الصــفحات 100-101) (عبـــاللاه، 2008، ص136)\&(لازم، 2019، ص14) بأن اللجوء إلى القضـاء بخصوص تلك 
المنازعـات يـؤدي إلـى نتــائج غيـر مرضـية سـواء للجهـات الرياضـية أم للرياضيين، وذلك للأسباب الآتية:

1- إن المنازعـات الرياضـية عمومًا تحتـاج إلى قضــاء متخصـص لديـه

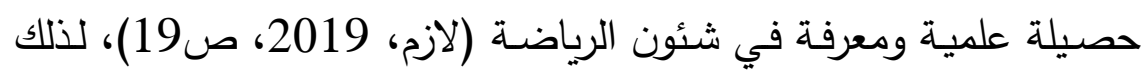
فإن الاتجاه السائد الآن، هو ضرورة أن يكون هناك قضاء متخصص سواء في المجالات المدنية أم التجاريـة أم الإداريـة أم العسكرية، كذلك الحال فى الى له المجال الرياضى، حيث أصبحت الرياضة ظاهرة اقتصادية تتمثل فى وجود عقود ذات قيمة مالية مرتفعة، والتى تثير العديد من المسائل المالية المعقدة التى تتسبب فى منازعات كثيرة ومتنوعة وتتطلب قاضى متخصص للفصل

$$
\text { فيها. (شوقي المليجي، 2005، ص101). }
$$

2- إن الخصوصـية التى يتسـم بها النشـاط الرياضـى تجعلـه غير قادر على تحمل البطء فى إجراءات فض النزاعات الناشئة عنها؛ فهى تحتاج إلى سرعة البت فيها من خلال ايجاد حلول تتلائم مع ظروف المتقاضين. 3- إن غالبيـة لـوائح الاتحـادات الرياضـية الدوليـة والوطنيـة وأنظمتهـا، حظرت على أطراف المنازعات الرياضية اللجوء إلى القضاء العادى، بسبب حـرص أطـراف النشـاط الرياضـى على أن تكـون نزاعـاتهم فيمـا بيـنهم،

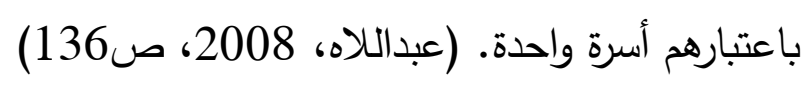

وقد رأينـا أن القضــاء الإدارى كـان لا يقبـل الطعـن على قـرار الاتحساد الرياضـى المختص إلا بعد أن يمر الطـاعن بكافـة طرق الطعن الداخلية التى تتص عليها لوائح الاتحاد أولًا. 
4- كما أن موقف المحاكم الداخلية للدول قد تغير فيما يتعلق بأعمال الرياضــة؛ فــع تــلـل القضــاء فـى المجـال الرياضـى على الرغم مـن قلـة الخبرات والاختصـاص وعدم الإلمام بالتنظيم الرياضى والقواعد الرياضية، أثمر عن قيام ممثلى الحركة الرياضية بإنثاء لجان تأديبية لحماية وتطبيق قواعـد الرياضـية، فظهـر التحكيم الرياضــي الـولي، وتـم إنشــاء المحكمـة الرياضية الدولية. (الشاعر، 2020، ص24)

5- لهذه الأسباب كان لابـد من البحث عن وضـع آلية خاصـة للفصل وتسوية المنازعات الرياضية، كالتحكيم الرياضسى باعتباره الوسيلة المثلى

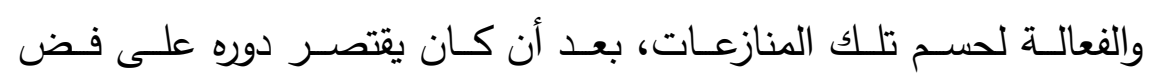
المنازعـات المدنيـة والتجاريـة وبعض المنازعـات الإداريـة، ولا يعنـى ذلك التقليل من دور القضـاء في فض المنازعة الرياضية. فاللجوء إلى التحكيم الرياضي أيًّا كانت صورته سواء باللجوء إلى مركز تحكيم داخلي أم دولي لن يحول دون اللجوء إلى القضاء، حيث تستطيع فرض رقابته إذا ما طعن على أحكامه بالبطلان أو حتى إذا ما طلب تتفيذها، حيث يتعين الحصول على أمر به من المحكمة المختصة. (شوقي المليجي، 2005، ص199)

\section{المطلب الثاني}

\section{دور التحكيم في فض المنازعات الرياضية}

مما لا شك فيه أن ما شهدته وما تزال تشهده حركة النشاط الرياضي من تطور خلال العقود الماضية إلى أن بلغت ذروتها في الوقت المعاصر، قد نتج عنه العديد من النزاعات المختلفة بين العديد من المشتغلين بالنشاط الرياضي

محمد عبد التواب (التحكيم في المنازعات الرياضية في القانون المصري.......) 
(الثاعر، 2020، ص25)، وهو الأمر الذي جعل من الأهمية بمكان ضرورة البحث عن آليـة أخرى تكون فعالـة وسريعة لحل هذه النزاعات فتم اعتمـاد التحكيم للقيام بهذا الدور لاسيما أن اللجوء إلى التحكيم في المجال الرياضي لا يحول دون اللجوء إلى القضاء إذا ما طعن على أحكامها بالبطلان أو حتى إذا مـا طلب تتفيذها، حيـث يتعـين الحصـول على أمسر بـه مـن المحكمـة المختصـة. ونحاول في هذا المقام أن نتــاول بالدراسـة دور التحكيم في فض المنازعات الرياضية في كل من مصر وفرنسا كما يلي:

\section{أولاًا: دور التحكيم فى فض المنازعات الرباضية في مصر:}

فقبل صدور قانون الرياضـة المصري الحالي رقم 71 لسنة 2017، كان يمكن تصوير اللجوء إلى التحكيم من خلال النص في أنظمة ولوائح الهيئات

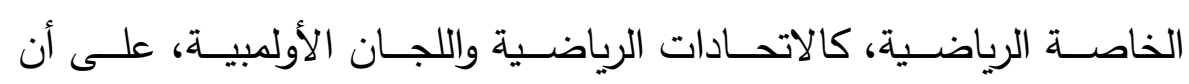
المنازعات التي تتشـأ بين تلك الهيئات وأحد أعضـائها أو أي من الممارسين للنشاط الرياضي الذى تتولى تتظيمه يتم عرضه ابتداءً على الأجهزة المختصـة بهذه الهيئات لتبدى رأيها، فإذا لم يرتضسى أحد الطرفين مـا انتهت إليه من قرارات لجأ إلى جهة التحكيم. (شوقي المليجي، 2005، ص187)

وبصدور قانون الرياضة الحالي رقم 71 لسنة 2017، تغير الوضع تمامًا ليشهد تطورًا تشريعيًا كبيرًا فيما يخص تتظيم النشاط الرياضي بكافة جوانبه، حيث تم الأخذ بنظام التحكيم الرياضسي، والنص على إنثـاء هيئة تحكيمية 
خاصــة بالفصـل في المنازعـات الرياضـية، وهــو مركـز التسـوية والتحكـيم

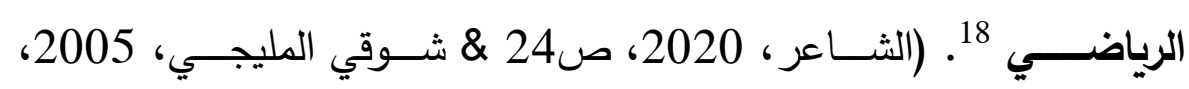
ص189)

فالمشـرع المصـري أفصـح عن ذلك، حين قرر إدخـال كافـة المنازعـات الرياضية الخاضعة لذلك القانون في نطاق مركز التسوية والتحكيم الرياضي، واعتمد تحكيمًا مستقًً قائمًا بذاته لنظر منازعات الرياضـة ومـا يتولد عنها، مانعًا أيسة جهـة أخـرى مـن مزاحمتــه فيهـا، بحيـث تمتـد صــلاحياته وولايتـهـ "التحكيميـة" إلى كافـة منازعـات النشـاط الرياضــي بالدولـة، أيَّا كـان موضـوع المنازعـة الرياضية، وهو مـا أكدت عليهه محكمة استئناف القاهرة في حكمها الصـادر في إحدى دعاوى التحكيم، حيث قررت بأنه: "وحيث إن القانون رقم 71 لسنة 2017 بشأن إصدار قانون الرياضة استحدث في بابه السابع نظامًا

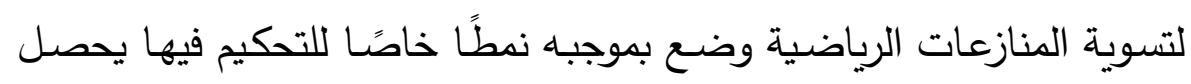
عن طريـق مـا يسـى مركز التسـوية والتحكيم الرياضـي المصـري تكون لـه الشخصية الاعتباريـة، يتولى تسوية المنازعات الرياضية الناشئة عن تطبيق أحكام هذا القانون، وذلك عن طريق الوساطة أو التوفيق أو التحكيم الرياضي. ونفاذًا للمادة 69 منه أصدرت اللجنة الأولمبية المصرية قرارها رقم 88 لسنة 2017 بلانحـة النظام الأساسـي لمركز التسوية والتحكيم الرياضـي المـكور، وحـددت اللائحسـة فـي طلبهـا القواعـد والضــوابط الخاصــة بمسـائل التحكـيم الرياضي، كيفيته والوسائل والإجراءات المتبعة في شأنه. والمستفاد من مواد القانون ولائحته التتفيذيـة "التحكيميـة"، أن المشرع اعتمد تحكيمًا مستقلًا قائمًا 
بذاتـه لنظـر منازعـات الرياضــة ومـا يتولـــ عنهـا، مانعًا أيـة جهـة أخرى مـن مزاحمته فيها، بحيث تمتد صـلاحياته وولايته "التحكيمية" إلى كافة منازعات

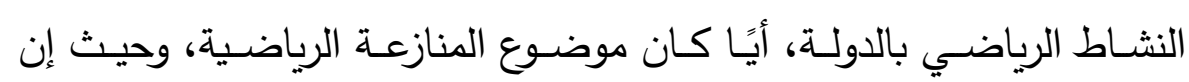
القاعدة المستقرة فقهًا وقضـاءً هي أن العام يحمل على عمومها والمطلق على إطلاقـه، بحيث لا يجـوز تخصسيص العـام بـدون مخصـص، وإذا كـان ذلك، وكانت نصوص قانون الرياضـة (ولائحتـه التحكيميـة)، قد وردت من الشمول والعموم - بصيغة عامـة دون تخصيص - وفى عبارات قاطعة الدلالة على أن المشرع الرياضـي، قد أفصـح عن قصده واضحًا وصريحًا في إدخال كافة المنازعات الرياضية الخاضعة لذلك القانون في نطاق مركز التسوية والتحكيم الرياضي، بعدوم ألفاظه فإن المنازعات الانضباطية والتأديبية والإدارية والمالية والعقدية، سواء بناء على شرط أو مشارطة تحكيم رياضي يرد في عقد، أو يرد بناءً على لائحة هيئة أو لائحة متعلقة بنشاط رياضـي (أحكام المادتين 66، 67 مـن القـانون)، تنـدرج جميعهـا - مــع تفاوتهـا واختلاف مجالاتهـا وتنـوع مصـادرها - تحت نطاق اختصـاص ذلك المركز الرياضي دون غيره، وبذلك يكون المشرع قد انتهج، بقواعد ثابتـة جامدة، نهجًا واضـحًا في شأن تحرير المنازعـات الرياضـية كافـة، كوحدة واحـدة ونسـيجًا واحدًا، مـن اختصـاص القضـاء، بحيث تنحسر ولايـة المحاكم عنها، وصـارت تلك المنازعات تندرج بالضرورة وبلا مجاملة تحت نطاق مركز التسوية والتحكيم الرياضي"19. 


\section{ثانيا: الوضع في فرنسا:}

كما سبق وأن ذكرنا فإنه في ظل قانون الرياضـة الفرنسي رقم 596 لسنة 2006، نجد أن المشرع كان قد أفرد فصلًا كاملً عند تحديده للجهة المختصة بنظـر المنازعـات الرياضـية، وهـو الفصـل الأول، حيـث جـاء تحـت عنـوان: "اللجنـة الوطنيـة الأولمبيـة والرياضـة الفرنسية"، مـن الباب الرابع: "هيئات التمثيل والتوفيق"، ونصت الفقرة الرابعة من المادة 141 من هذا الفصل على اختصاص اللجنة الأولمبية الوطنية والرياضية الفرنسية بالفصل في المنازعات الرياضية من خلال التوفيق في النزاعات بين المرخصين والجمعيات الرياضية والاتحادات الرياضية المعتمدة باستثناء النزاعات التي تشمل المنشطات.

وبهذا النص التشريعي يكون المشرع الفرنسي كان قد سـاهم هو الآخر بـدوره في التحـول إلـى التحكيم الرياضـي كوسـيلة كُثلى لفضى المنازعـات الرياضـية، حيـث أن التجـارب الماضـية أثثتـت أن الأحكـام القضــائية التي صدرت فيما يخص الأنشطة الرياضية، لم تكن فاعلة في النهوض بالرياضـة وهو ما أدى بالمشرع الفرنسي أيضًا إلى الإلتجاء إلى التحكيم كوسيلة للفصل

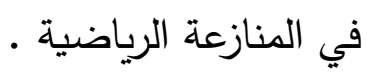




\section{الخاتمة:}

تعرضنا في هذا البحث إلى بيان الدور الذي يقوم به التحكيم في فض المنازعـات الرياضـية ويتجلى هـذا الـدور فيمـا قـام بـه المشـرعين المصـري والفرنسي من إصدار قوانين مستقلة لمواكبة التطورات الحديثة التي طرأت على الرياضــة والذي خـلا من تنظيمها قوانين الرياضــة السـابقة حين قرر المشرع المصري إصدار قانون الرياضـة رقم 71 لسنة 2017، والذي ألغى رقم 77 لسنة 1975 بشأن الهيئات الخاصة بالشباب والرياضة، وفيه أفرد المشرع بابًا كاملًا - وهـو الباب السـابع - للمنازعـات الرياضـية، تحـت عنـوان: "تسوية المنازعـات الرياضـية" كمـا أدخل كافـة المنازعـات الرياضـية الخاضـعة لهـا القانون فى نطاق مركز التسوية والتحكيم الرياضى، كما اعتمد المشرع للمركز سـالف الذكر تحكيمًا مستقلًا قائمًا بذاته لنظر منازعات الرياضــة ومـا يتولد عنها، مانعًا أية جهة أخرى من مزاحمته فيها، بحيث تمتد صـلاحياتها وولايتها

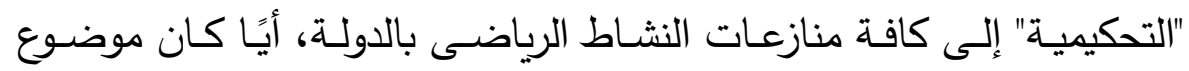

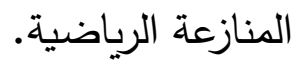

كما أن المشرع الفرنسي هو الآخر أصدر قانون الرياضـة رقم 596 لسنة 2006 والذي ألغسى بـدوره قانون الرياضــة الفرنسي القديم، الصـادر في 16 يوليو 1984، وتضمن أحكامًا خاصـة بتسوية المنازعات الرياضية والتحكيم؛ حيث أفرد المشرع فصلًا كاملًا عند تحديده للجهة المختصـة بنظر المنازعات الرياضـية، وهو الفصـل الأول، حيث جـاء تحـت عنـوان: "اللجنـة الوطنيـة

محمد عبد التواب (التحكيم في المنازعات الرياضية في القانون المصري.......) 
الأولمبيـة والرياضـة الفرنسية"، من الباب الرابع: "هيئات التمثيل والتوفيق"، ونصت الفقرة الرابعة من المادة 141 من هذا الفصل على اختصاص اللجنة الأولمبية الوطنيـة والرياضـية الفرنسية بالفصل في المنازعات الرياضية مـن خلال التوفيق في النزاعات بين المرخصين والجمعيات الرياضية والاتحادات الرياضية المعتمدة باستثناء النزاعات التي تشمل المنشطات.

فتعرضنا في البدايـة لبيان المقصود بالمنازعـة الرياضية -ابتداءًا وانواع تلك المنازعات على الصعيدين المحلي والدولي، ثم تعرضنا لموقف كرًا من المشرعين المصري، الفرنسي على النحو السابق بيانه ومدى إسهام كلً منهم في حـل المشـكلات والقضـايا الرياضـية على إختلاف مسـتوياتها، بتسـوية المنازعات بين الأطراف الرياضية، لتحقيق الاستقرار للهيئات الرياضية.

واقتضـت طبيعـة الدراسـة بيان دور القضـاء في فض المنازعـة الرياضية لاسيما دوره في هذا الثأن قبل إصدار قوانين الرياضة الحالية التي جعلت من التحكيم هو الوسيلة المُّثلى لفض تلك المنازعات بعيدًا عن اللجوء إلى القضـاء على النحو السابق بيانه.

وانتهينـا إلى أن طبيعـة الأنشـة الرياضـية الخاصـة جعلـ المنازعـات الرياضية تتمتع هي الأخرى بخصوصية تختلف عن غيرهـا من المنازعات

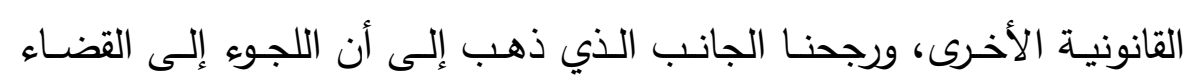
بخصـوص تلـك المنازعـات يـؤدي إلى نتـائج غيـر مرضـية سـواء للجهات الرياضية أم للرياضيين، وأفردنا لذلك اسبابًا تتاولناها بالسرد والتفصيل. 
ويتضح مما سبق أنه يمكن للباحث أن يخرج بيغ النتائج والتوصيات

الآتية:

أولاًا: النتائج:

1- لا شك وأن خروج قوانين جديد للنور تتعلق بالرياضـة سواء في مصر

أم فرنسا، هو إنجاز كبير للمشرعين المصري والفرنسي، وذلك حيث ساهما

كلًا منهمـا بشكل كبير فى حل العديد مـن الإشـكاليات المتعلقـة بالمجـال

الرياضسى، والتى عجزت القوانين القديمة عن تقديم حلول لها، ومنها الطب

الرياضـى والمنشطات والاستثمار فى المجال الرياضسى والمحاكم الرياضية،

وفكرة إنشاء مركز للتحكيم الرياضس، وغيرها من الأمور التى عجز قانون

الرياضة القديم رقم 77 لسنة 1975 عن حلها في مصر ، والقانون رقم 610

/ 84 الصادر في 16 يوليو 1984 في فرنسا لعدم مواكبته التطورات سابقة

البيان التى طرأت على الرياضة.

2-كمــا أنـه يتضــح باسـتقراء نصـوص قـانون الرياضــة رقم 71 لسـنة

2017، مدى التباين والاختلاف بينه وبين قانون التحكيم المصرى رقم 27 لسنة 1994 فى بعض النقاط منها مدى التميز الواضح لسلطة هيئة التحكيم فى اتخاذ التدابير الوقتية والتحفظية، حتى إذا لم يوجد اتفاق بين أطراف النزاع على منح هيئات التحكيم الرياضـى تلك السلطة طبقًا لمـا هو وارد بنصـوص اللائحسة المنظمـة لإجـراءات التحكيم بمركـز التسـوية والتحكيم الرياضى، بخلاف قانون التحكيم الذى ينص على ضرورة وجود اتفاق خاص

محمد عبد التواب

(التحكيم في المنازعات الرياضية في القانون المصري.......) 
بين الأطراف المتازعة يتيح لهيئة التحكيم اتخاذ التدابير الوقتية والتحفظية سابق الإشارة إليها، وفى حالة عدم وجود اتفاق خاص، فتتعقد سلطة اتخاذ

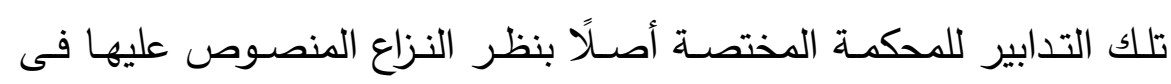
المادة التاسعة من قانون التحكيم رقم 27 لسنة 1994. 3-كما تتميز إجراءات التحكيم الرياضسى عن إجراءات التحكيم العـادى الواردة، التى نص عليها فى قانون التحكيم رقم 27 لسنة 1994، من أنه الهـ يجوز الطعن بطريـق الاستئناف على جميع الأحكام الصــادرة مـن مركز

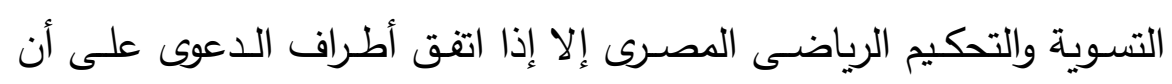
يعتبر حكم التحكيم نهائيًا. فى حين أن قانون التحكيم المصرى يقضى بعدم

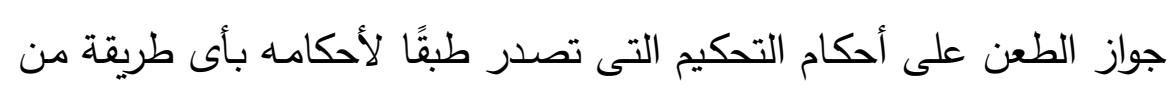
الطرق المنصوص عليها فى قانون المرافعات المدنية والتجارية إلا من خلال دعوى بطلان حكم التحكيم

4- يكرس التحكيم الرياضـي لعدة مبادئ هامـة منهـا مبدأ حربـة الإرادة في ليط

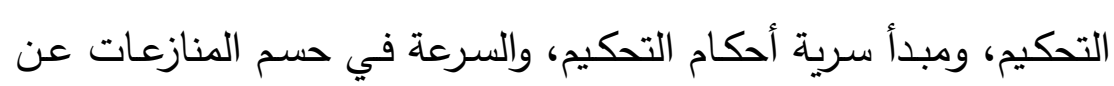
طريق تقليل الوقت والجهد، كما يرستخ التحكيم الرياضي من دعائم مبدأ نزاهة وحياد المحكم.

محمد عبد التواب (التحكيم في المنازعات الرياضية في القانون المصري.......) 
ثانتًا: التوصسيات:

\section{يوصي الباحث:}

1. أوصي المشرع المصري بإعادة النظر في تعديل نص المادة 66 من

قانون الرياضة الجديد رقم 71 لسنة 2017 فيما جعله من اختصاص مجلس إدارة اللجنة الأولمبية المصرية بإصدار لائحة النظام الأساسي لمركز التسوية والتحكيم الرياضـي المصري، بما يخل باستقلال وحيدة هيئات التحكيم التابعة له، حيث أن الروابط والقواسم المشتركة بين مركز التسوية والتحكيم الرياضي المصرى واللجنـة الأولمبية المصرية من شأنها إثارة شكوك جدية حول مدى اسـقلال المركز لاسـيما فـى الحـالات التـى قد تكون فيهـا اللجنـة الأولمبيـة المصرية طرفًا فى الدعاوى المعروضـة على أى من هيئات التحكيم، وهو ما جعل تلك المادة محلًا للنقد ومن ثم إثارة الثكوك حول دستوريتها.

2. أوصى بأن يكون المسئول عن تشكيل واختيار المستشارين والمحكمين من وزارة العدل بالتسيق مع وزارة الرياضة واللجنة الاولمبية، كما يوصي بأن تتم تحديـد إجراءات التقاضـى فى قـانون الرياضــة ذاته، وليس فـى اللائحسة الخاصة بالمركز على النحو السابق، تحسبًا لعدم اعتبار ذلك تدخلً حكوميًّا.

3. كما أوصي بأن يستقل مركز التسوية والتحكيم الرياضسى عن للجنة

الأولمبية - كما سبق القول - حيث إن تولى رئيس اللجنة الأولمبية بصفته رئاسـة مجلس إدارة مركز التسوية والتحكيم الرياضسى، يقلل من حيدة المركز ،

محمد عبد التواب (التحكيم في المنازعات الرياضية في القانون المصري.......) 
وخصوصًا إذا كـان أحد أطراف النزاع المطروح أمامـهـ هـى اللجنـة الأولمبيـة

نفسها، وذلك من أجل أن يكون هناك ضمان أكثر لحيدة واستقلال المركز .

4. أوصسى بضرورة نشر الوعي فيما يخص أحكام الفيفا في الهيئات

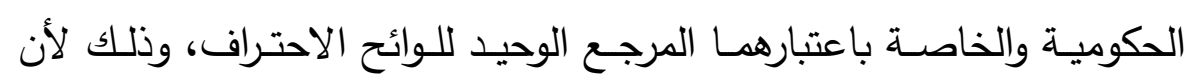

معظم أفراد المجتمع لا دراية له بتلك الأحكام.

5. كما أوصي بإقامة دورات تدريبية وندوات ولقاءات لتعريف المحكمين

المتخصصين بالتشريعات والقوانين الرياضية الذي يكرس للاعتماد على خبراء

رياضيين مؤهلين ومتخصصين في هذا المجال.

محمد عبد التواب

(التحكيم في المنازعات الرياضية في القانون المصري.......) 


\section{الهوامش}

أ- مجموعة الأعمال التحضرية للقانون المدني المصري، الجزء الخامس، ص303.

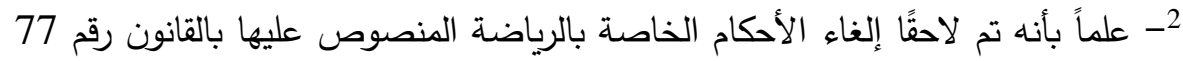

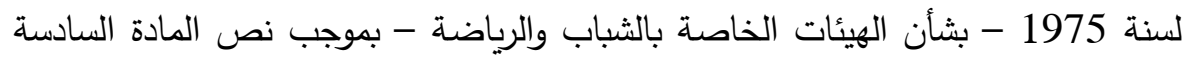
من قانون الرياضة رقم 71 لسنة 2017. 3- الطعن رقم 28120، 28605 لسنة 54 ق عليا جلسة 2008/7/8 المجانة 2017 المعوعة 53 الجزء 2 ص1556 مجموعة المبادئ القانونية التي قررتها المحكمة الإدارية العليا فى ربع فلها قرن ص1813. 4 رقم 218 لسنة 2017 بثأن قانون تنظيم الهيئات الثبابية.

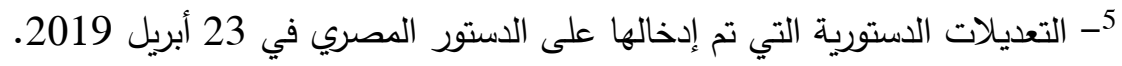

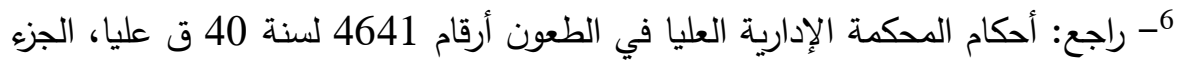
الأول، المجموعة 43 ص231، جلسة 1997/11/2، وأيضًا الطعن رقم 584 لسنة 50 ق المجموعة 49 جلسة 2004/2/12 ص354 ق عليا أحكام مشار إليها بمجموعة

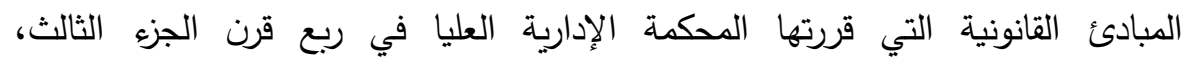
ص1814. 7- الجريدة الرسمية العدد (21) مكرر (ب) في 31 مايو 2017. 8- علماً أنه قد صدر القانون رقم 7 لسنة 2020 وأدخل عدة تعديلات فئل على القانون المذكور منها اخضاع جميع مراكز الثباب لمنظومة قانونية واحدة بما يضمن انتظام عملها

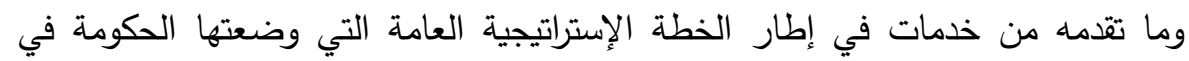
خصوص فئة الثباب. 9 - مثل اللجان الأولمبية الدولية والوطنية. 10 - المادة (10) من قانون 47 لسنة 1972 بثأن مجلس الدولة.

محمد عبد التواب (التحكيم في المنازعات الرياضية في القانون المصري.......) 
11 الطعون أرقام رقم 6489، 6951، 6958 لسنة 43 ق عليا جلسة 2003/4/5 الجزء 48 ص645، مجموعة المبادئ القانونية التي قررتها المحكمة الإدارية العليا في ربع قرن،

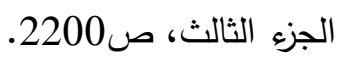

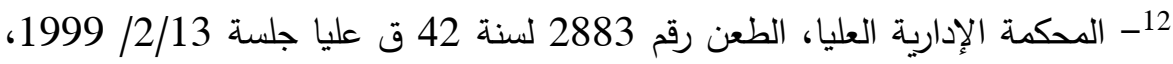

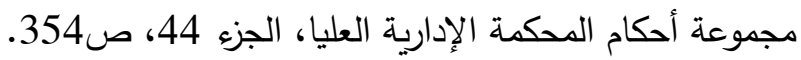
13- أحكام المحكمة الإدارية العليا في الطعون أرقام 4641 لسنة 40 ق علية صليا، الجزء الأول، المجموعة 43، ص231 جلسة 1997/11/2، وأيضًا الطعن رقم 584 لسنة 50 ق المجموعة 49 جلسة 2004/2/12 ص 354 سابق الإثارة إليها.

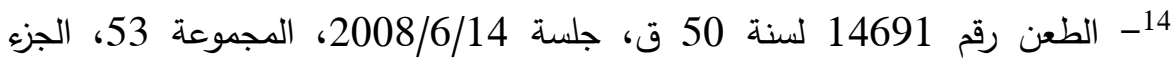

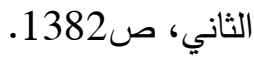

15- قضت الدائرة التجارية والاقتصادية بمحكمة النقض، في الطعن رقم 1458، لسنة

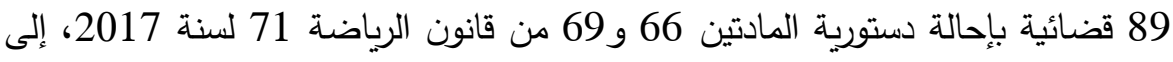

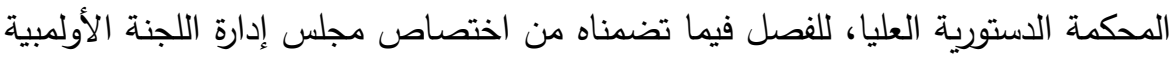

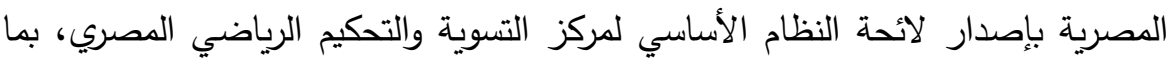

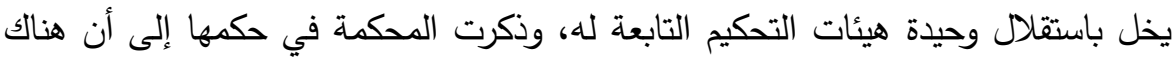

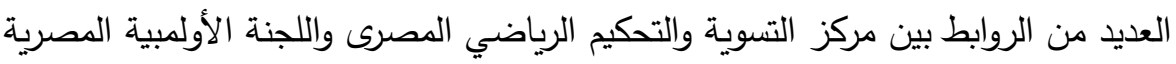

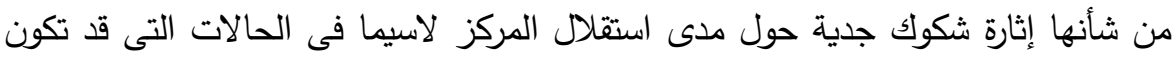

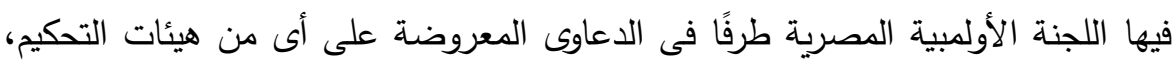

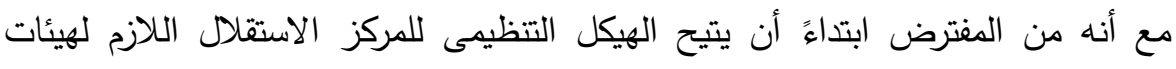

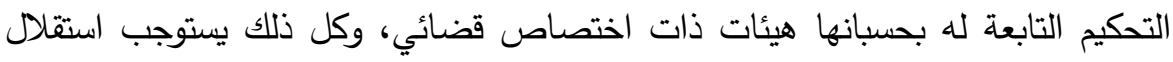

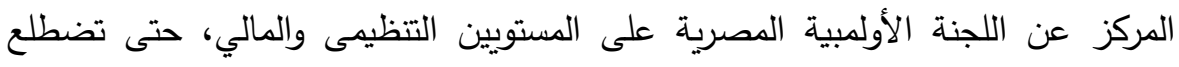
هيئات التحكيم التابعة للمركز بالفصل فى دعاوى التحكيم المطروحة عليها من خلال

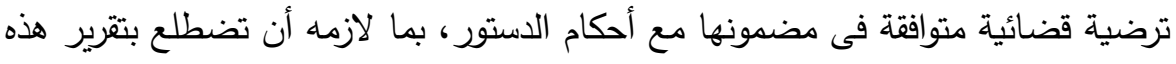

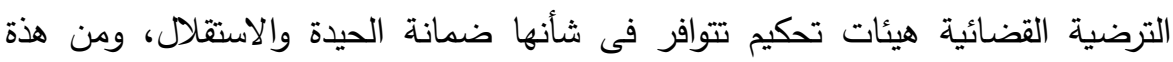

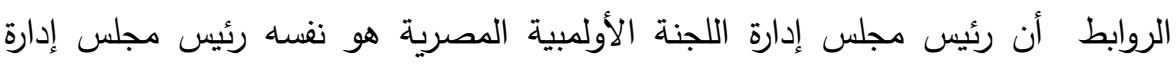

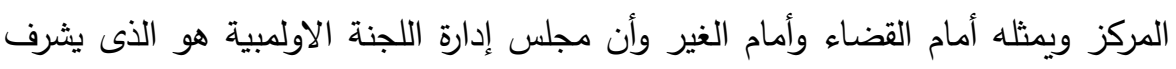

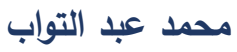

(التحكيم في المنازعات الرياضية في القانون المصري.......) 
على شئون المركز من كافة النواحي المالية والإدارية وكذلكتشكيل المركز، ووضع لائحة

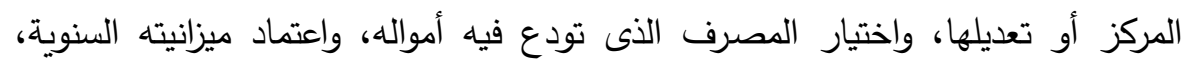
واعتماد تعيين الأمين العام والعاملين بالمركز .

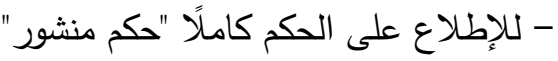

https://egyptfans.club/2020/01/02/\%D9\%85\%D8\%AD\%D9\%83\%D9 \%85\%D8\%A9-\%D8\%A7\%D9\%84\%D9\%86\%D9\%82\%D8\%B6\%D9\%82\%D8\%A7\%D9\%86\%D9\%88\%D9\%86\%D8\%A7\%D9\%84\%D8\%B1\%D9\%8A\%D8\%A7\%D8\%B6\%D8\%A9\%D9\%85\%D8\%AE\%D8\%A7\%D9\%84\%D9\%81\%D9\%84\%D9\%84\%D8\%AF\%D8\%B3\%D8\%AA 16- صدر هذا الحكم بمناسبة الطعن المقدم من رئيس نادي الزمالك ضد الحكم الصادر

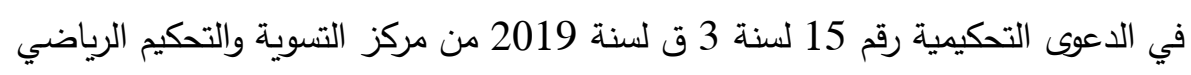

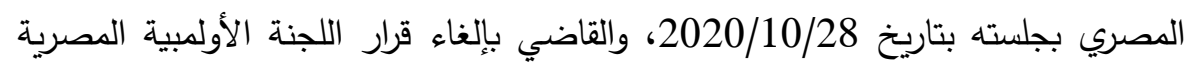

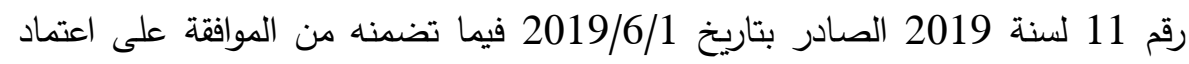
لائحة النظام الأساسي لنادى الزمالك المعدلة وما يترتب على ذلك من آثار. 17 - 1اجع: - 1انظ:

C.E. sect. 22nov. 1974, fédération des indusdires françaises d'articles de sport, recueil du conseil d'Etat, p.576, concl.J.thry وقد قضي بأن: "La responsabilité d'une fédération sportive délégatoire - peut être recherchée devant le juge administratife pour les préjudices engendrés par une décision illégale qu'elle a prise à l'égard d'un club et qui s'analyse en une décision administrative", CAA Paris, 8 avr. 2003, D.2003 J.P. 2539, obs, J.F. lachaum.

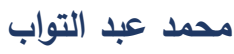

(التحكيم في المنازعات الرياضية في القانون المصري.......) 
C.E., 20 janv. 1989 , fédération française de karaté requête No. 73.762

- أشار إليه د. أسامة أحمد شوقي المليجي، مرجع سابق ص165 هامش رقم 2.

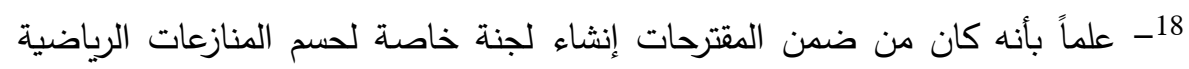

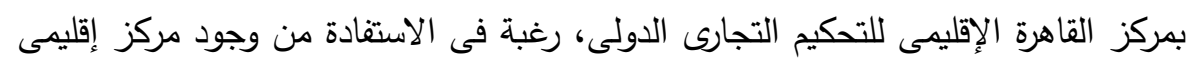

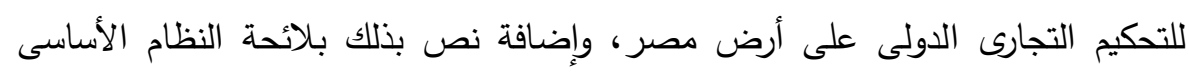
للاتحاد الرياضى، ويوافق عليه أعضاء الجمعية العمومية غير العادية.

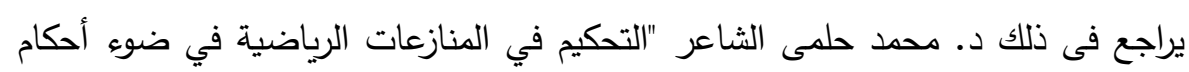

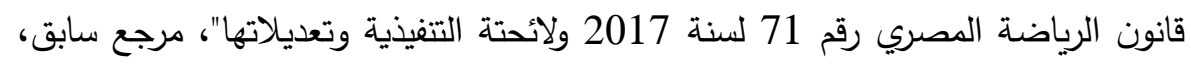

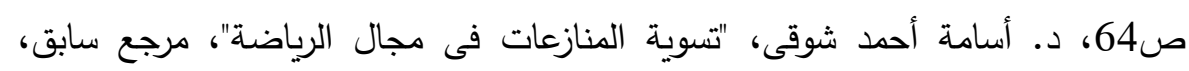
ص189 صما بعدها.

19 - الحكم الصادر في دعوى التحكيم رقم 29 لسنة 135 قضائية استئناف القاهرة جلسة $.2019 / 4 / 17$

محمد عبد التواب

(التحكيم في المنازعات الرياضية في القانون المصري.......) 


\section{قائمة المصادر والمراجع}

\section{أولًا: المرجع العربية:}

1. د.محمد حلمي الثـاعر : "التحكيم في المنازعات الرياضية في ضوء

أحكـام قـانون الرياضــة المصـري رقـم 71 لســـة 2017 ولائحتـهـ التنفيذيـة

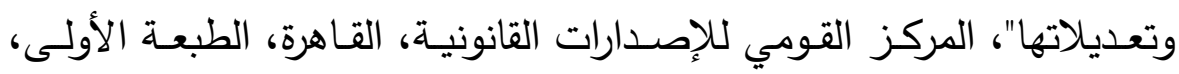
-2020 2. د.حسـين جبـار لازم: "الفصـل فـي المنازعـات الرياضـية بـالتحكيم"، منشورات الحلبي الحقوقية، الطبعة الأولى 2019م. 3. جمال عبد الرحمن محمد علي، "الالتزام بضمان السلامة في المجال الرياضي"، بحث منشور بمجلة العلوم القانونية والاقتصـادية - كلية الحقوق الحترم جامعة عين شمس، العدد الثاني، السنة الثالثة والخمسون - يوليو 2011. 4. د.بشـار عدنان ملكـاوي، أ.محمــ جمـال يوسـف نعـلاوي: "مسـؤولية الأنديـة الرياضـية عـن الإخـلال بالتزاماتهـا المتعلقـة بعقـود انتقـال اللاعبـين الرياضـيين"، بحـث منشـور بمجلـة العلـوم السياسـية والقـانون، العـدد الثالـث والعشرون - يوليو 2020، المركز العربي الديمقراطي للدراسات الاستراتيجية والسياسية والاقتصادية، برلين - ألمانيا.

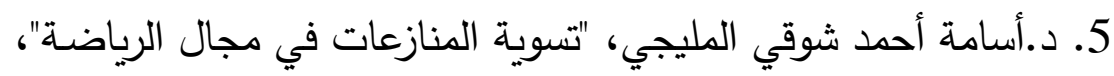
دار النهضة العربية، القاهرة، 2005. 6. د.رجب كريم عبد الـلاه "عقد احتراف لاعب كرة القدم"، دار النهضـة العربية، القاهرة،

محمد عبد التواب (التحكيم في المنازعات الرياضية في القانون المصري.......) 
7. د.عبد الحميد عثمان الحفني، "عقد احتراف لاعب كرة القدم مفهومـة،

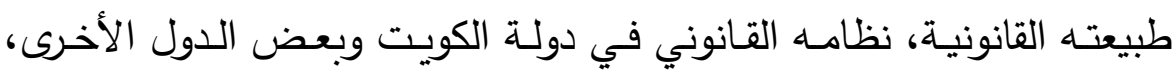
"بحث ملحق بمجلة الحقوق الكويتية - العدد الرابع - الطبعة الأولي، 1995.

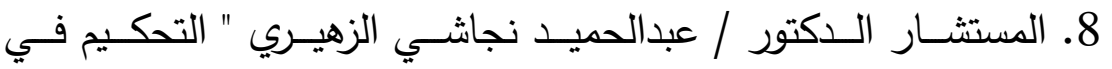
المنازعات الرياضية، دراسة في ضوء قانون الرياضـة المصري رقم 71 لسنة

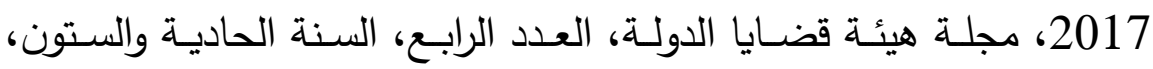

$$
\text { أكتوبر - -ديسمبر ، } 2017 .
$$

9. حوراء عزيز الموسوي، "لمحة تعريفية عن قضـاء التحكيم الرياضي"، بحث منشور بمجلة كربلاء لعلوم التربية الرياضية جامعة كربلاء.

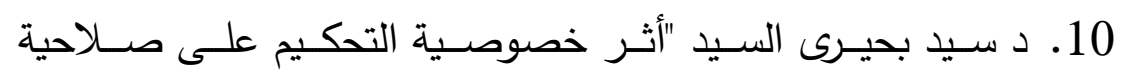
المحكم"، رسالة دكتوراة كلية الحقوق جامعة عين شمس 2019.

\section{ثانيًا: المراجع الأجنبية}

1- Grande dictionnair Larousse, T.14, 1985 ,

2- G. Magnane, Situation du sport dans la société contemporaine; dans jeux et sports, La pléiade , 1967.

3- A. Abou el wafa, la réglementation international du droit de sportp. 24.

4- L'ordonnance N. 2006 - 596 du 23 mai 2006 rélative à la partie législative du code du sport.

5- F. Buy,J-M. Marmayou. D. Poracchia, et F. Rizzo, Droit du sport, LGDJ, 2006.

$* * *$

محمد عبد التواب

(التحكيم في المنازعات الرياضية في القانون المصري.......) 


\section{Arbitration in sports disputes in Egyptian and French law \\ "A comparative study" \\ Mohamed Abdel Tawab Abdel Hassib}

\section{Abstract:}

It was necessary to search for a legal mechanism to resolve judicial disputes in Egypt and France, in light of the global trend of resolving sports disputes by non-judicial methods such mediation, conciliation and arbitration.

When can we guarantee that none of the athletes and the parties to sports disputes will resort to the courts, because sports disputes enjoy a special nature that makes it better not to confront the courts to separate them. In addition, the fact that sports arbitration may contribute significantly to resolving sports disputes that the courts are unable to resolve with the consolidation that involve applying set of legal rules that aim to settle it as a final and decisive settlement, which together constitute the legal system and that is called sports arbitration.

Therefore, the Egyptian legislator issued the Sports Law 71 for 2017. the establishment of centers for settlement and arbitration for Egyptian sports, the same is true of the French legislator, who promulgated the sports law No,596 of 2006 which stipulated that the National Olympic and French Sports committee is required to adjudicate in Rabiad associations and approved consensual federations, with the exceptions of disputes involving associations. 